\title{
Tieto ja eläinsuhde hevosten pidossa
}

\author{
Nora Schuurman \\ Itä-Suomen yliopisto, Joensuun kampus, PL 111,80101 Joensuu,nora.schuurman@uef.fi
}

Tiivistelmä

Yhteiskunnan eläinsuhteen muuttuessa on seuraeläinten merkitys vapaa-ajassa korostunut. Osana tätä ilmiötä voidaan myös nähdä hevosen roolin muuttuminen työtä tekevästä eläimestä yhä suositummaksi urheilu- ja harrastustoveriksi. Uudelle hevossuhteelle on tyypillistä kaupunkilaisten aktiivinen hakeutuminen hevosten pariin vapaa-ajallaan ja pyrkimys läheiseen suhteeseen hevosensa kanssa. Hevosesta haetaan eläinystävää, joka tarjoaa monenlaisia toimintamahdollisuuksia kuten luonnossa liikkuminen, samanhenkisten ihmisten kanssa toimiminen ja kilpaurheilu.

Muutokset eläimiin suhtautumisessa heijastuvat eläinten pitoa koskeviin käsityksiin ja niistä syntyviin käytäntöihin. Eläinten pito paitsi edellyttää tietoa ko. eläimestä, myös tuottaa sitä eläimen omistajalle arkisen toiminnan ja vuorovaikutuksen kautta. Tieto onkin eräänlainen portti eläinten pitoon, väline, jonka avulla ihmisen ja eläimen maailmojen on mahdollista kohdata ja eläinten säilyä hengissä ihmisen hallitsemassa ympäristössä. Eri lähteistä ja eri tavoin hankittu tieto vaikuttaa myös käsityksiin eläimen hyvinvoinnista sekä hyvinvoinnin tulkintaan.

Tässä artikkelissa tarkastelen eläinten yhteiskunnallisen aseman muutosta ihmisen ja hevosen suhteen kautta, harrastehevosten pidon kontekstissa. Lähestyn aihetta erityisesti tiedon näkökulmasta kysymällä, millä tavoin ihmisen suhde eläimeen on riippuvainen eläintä koskevasta tiedosta. Kysyn myös, miten tieto ja eläinsuhde vaikuttavat eläimen hyvinvoinnin tulkintaan sekä miten eläintä koskevaa tietoa tuotetaan vuorovaikutuksessa eläimen kanssa. Artikkeli perustuu vuonna 2007 tehtyihin hevosenomistajien haastatteluihin.

Haastatteluista ilmenee, että emotionaalisuus on keskeistä harrastehevosten omistajien eläinsuhteessa, mutta siinä on myös viitteitä välineellisestä ajattelusta. Hevosenomistajat tulkitsevat hevosiaan usein inhimillistävästi, mutta toisaalta myös luonnontieteellisesti tai luonnollistavasti. Luonnollistavaa tulkintaa, jossa eläimen biologista olemusta korostetaan, käytetään inhimillistävän tulkinnan rinnalla myös yksilötasolla. Tällöin eläimen tuntoja ja toimintaa tulkitaan verbaalisesti, mutta sitä ei verrata ihmiseen, vaan se nähdään nimenomaan eläimenä.

Tulkintojen erolla on merkitystä silloin, kun niitä käytetään toiminnan lähtökohtana hevosten hoidossa tai käsittelyssä. Kun eläin nähdään eläimenä, tulkinta perustuu siihen, mitä eläimestä tiedetään ja millainen käsitys siitä on muodostunut tuon tiedon pohjalta. Myös hevosen tunteminen yksilönä on tärkeää. Tieteeseen perustuvasta, eksplisiittisestä tiedosta pyritään hakemaan yleisiä ohjeita ja käsitystä hevosesta luonnollisena eläimenä, ja käytännön tilanteissa ja niistä tehtävissä tulkinnoissa tiedon eri lajit kietoutuvat yhteen. Hevosten pidossa on olennaista hiljainen tieto, joka ilmenee käytännöllisen kokemuksen antamana intuitiivisena varmuutena, mutta myös erityisenä taitona "lukea" hevosta ja tulkita sen viestejä ja olotilaa. Tällä on keskeinen merkitys eläimen hyvinvoinnin määrittämisessä arkisissa hoito- ja käsittelytilanteissa. Hyvinvointia määritetään sekä inhimillistävistä että luonnollistavista lähtökohdista sen mukaan, minkätyyppisen tiedon ja kokemusten pohjalta eläintä tulkitaan.

Aineiston perusteella eläinsuhde rakentuu kerroksellisesti eksplisiittisen tiedon, hankittujen kokemusten sekä inhimillistävän ja luonnollistavan tulkinnan varaan, ja käsitykset eläimistä tuottavat myös ristiriitaisia tulkintoja. Lisäksi omistajan suhde hevoseen, kokemus ja taito lukea hevosta antavat hevoselle itselleen roolin toimivana subjektina ja yhteisön jäsenenä, joka osallistuu itseään koskevan tiedon muodostamiseen ja pääsee vaikuttamaan välillisesti myös omaan hyvinvointiinsa.

Asiasanat: hevonen, eläinsuhde, seuraeläin, antropomorfismi, hiljainen tieto 


\section{Johdanto}

Yhteiskunnan eläinsuhteen muuttuessa on seuraeläinten merkitys vapaa-ajassa korostunut samalla, kun eläinsuhteen on nähty muuttuvan on tapahtunut muutos välineellistävästä emotionaaliseen suuntaan (Franklin 1999). Ilmiö on osa laajempaa yhteiskunnallisen eläinsuhteen muutosta viime vuosikymmenten aikana, ja sen taustalla on nähty etääntyminen luonnosta, vapaa-ajan lisääntyminen, yksilöllisyyden korostuminen sekä erityisesti kaupungistuminen (Franklin 1999; Buller \& Morris 2003). Osana tätä prosessia voidaan nähdä muutokset hevosten pidossa, kun työhevosten tilalle ovat tulleet urheilu- ja harrastehevoset.

Hevonen on aina ollut kotieläimenä erityinen: sen rooli on ollut keskeinen modernin yhteiskunnan rakentamisessa niin maataloudessa, kuljetuksissa, kaupunkien rakentamisessa, sodankäynnissä kuin teollisuudessakin (McShane \& Tarr 2007). Sitä on työkykynsä vuoksi myös pidetty suuremmassa arvossa kuin muita kotieläimiä (Hall 2005). Se on sopeutunut yhteiskunnan modernisaatioon sen eri vaiheissa ja löytänyt paikkansa myös nyky-yhteiskunnassa. Uudelle hevossuhteelle on tyypillistä kaupunkilaisten aktiivinen hakeutuminen hevosten pariin vapaa-ajallaan ja pyrkimys läheiseen suhteeseen hevosensa kanssa (Birke 2008). Hevosesta haetaan eläinystävää, joka tarjoaa monenlaisia toimintamahdollisuuksia kuten luonnossa liikkuminen, samanhenkisten ihmisten kanssa toimiminen ja kilpaurheilu.

Muutokset eläimiin suhtautumisessa heijastuvat myös hevosten pitoa koskeviin käsityksiin ja niistä syntyviin käytäntöihin. Eläinten pito paitsi edellyttää tietoa ko. eläimestä, myös tuottaa sitä eläimen omistajalle arkisen toiminnan ja vuorovaikutuksen kautta (Ingold 2000). Tieto onkin eräänlainen portti eläinten pitoon, väline, jonka avulla ihmisen ja eläimen maailmojen on mahdollista kohdata ja eläinten säilyä hengissä ihmisen hallitsemassa ympäristössä (Schuurman 2010). Eri lähteistä ja eri tavoin hankittu tieto vaikuttaa lisäksi käsityksiin eläimen hyvinvoinnista sekä hyvinvoinnin tulkintaan (Buller \& Morris 2003).

Tässä artikkelissa tarkastelen hevosen yhteiskunnallisen aseman muutosta eläinsuhteen ja tiedon näkökulmasta. Tutkimuskysymys on: Millä tavoin ihmisen suhde eläimeen on riippuvainen eläintä koskevasta tiedosta? Kysyn myös, miten tieto ja eläinsuhde vaikuttavat eläimen hyvinvoinnin tulkintaan sekä miten eläintä koskevaa tietoa tuotetaan vuorovaikutuksessa eläimen kanssa. Artikkeli perustuu vuonna 2007 tehtyihin hevosenomistajien haastatteluihin.

\section{Keskeiset käsitteet}

Eläinsuhde käsitteenä kertoo yksilön tai yhteiskunnan suhteesta eläimiin sekä niitä koskevista käsityksistä. Eläinsuhdetta voidaan tarkastella esimerkiksi emotionaalisena, välineellistävänä, tieteellistävänä tai inhimillistävänä (Franklin 1999; Ingold 2000; Kellert 2005). Eläinsuhteen emotionaalinen aspekti korostuu lemmikkieläinten kohdalla, joista on tullut entistä selvemmin perheenjäseniä (Franklin 1999). Lemmikkieläimistä käytetään nykyään usein myös käsitettä seuraeläimet (companion animals) kuvaamaan sitä tarvetta, minkä tyydyttämiseen niitä ensisijaisesti pidetään (Serpell \& Paul 1994). Syyt seuraeläinten pitämiseen ovat ennen kaikkea sosiaaliset ja emotionaaliset, mikä erottaa ne muista kotieläimistä, joiden tehtävänä on tuottaa omistajilleen etupäässä käytännöllistä ja/tai taloudellista hyötyä (Serpell \& Paul 1994).

Kissojen, koirien ja muiden pieneläinten lisäksi seuraeläimiksi lasketaan usein myös hevoset (Haraway 2004; Kellert 2005). Ratsastuksen harrastajat mieltävät hevosensa ystävinä ja yksilöinä, joiden kanssa he haluavat olla yhdessä (Birke 2008). Vaikka hevonen muistuttaakin länsimaisessa yhteiskunnassa lemmikkiä, sille on yhä tyypillistä, että sitä käytetään tiettyyn tarkoitukseen kuten urheiluun, ratsastuksen opetukseen tai harrastukseen. Hevonen ei myöskään asu omistajansa kanssa samassa tilassa eikä usein edes kodin yhteydessä vaan kaupungin ulkopuolella toimivalla täysihoitotallilla. Lisäksi se on virallisesti määritelty tuotantoeläimeksi.

Antropomorfismi voidaan määritellä ajatusmalliksi, jossa eläimiin liitetään ihmisen kaltaisia ominaisuuksia kuten ajatukset, tunteet, motivaatiot ja uskomukset (Serpell 2003). Franklinin (1999) mukaan tapa inhimillistää eläinten käyttäytymistä on lisääntynyt. Seuraeläinten pidossa se näkyy esimerkiksi sii- 
nä, miten lemmikeille annetaan ihmisten ruokaa, nimiä, syntymäpäiviä, monimutkaisia lääketieteellisiä hoitoja ja paikka lemmikkien hautausmaalta (Serpell 2003). Antropomorfismia on kritisoitu virheellisenä ajattelutapana erityisesti luonnontieteissä sillä perusteella, että eläinten ajattelusta ei voida saada varmaa tietoa. Lisäksi eläinten pitäminen ihmisten kaltaisina voi aiheuttaa hyvinvointiongelmia eläimelle itselleen, mikäli niiden tarpeet ja ominaisuudet ymmärretään samanlaisiksi kuin ihmisillä (Arluke \& Sanders 1996).

Eläinten käyttäytymistä tulkitaan arkikielessä kuitenkin usein antropomorfistisesti. Tapa puhua eläinten "puolesta" muistuttaa myös sitä, miten vaikeavammaisten lasten vanhemmat tulkitsevat lastensa käyttäytymistä ja puhuvat heidän puolestaan (Arluke \& Sanders 1996, 50). Tarkastelemalla eläintä ihmisen ja eläimen suhteen kautta annetaan myös tilaa vaihtoehtoisille hyvinvointitulkinnoille, joissa eläin otetaan huomioon subjektina, tuntevana yksilönä: eläimen kärsimys samoin kuin hyvinvointikin koetaan kuitenkin yksilötasolla. Luonnontieteellisen eläinten hyvinvointitutkimuksen täydentämiseksi onkin yhteiskuntatieteissä ehdotettu lähestymistapaa, joka korostaa omistajan ja eläimen välistä vuorovaikutusta ja eläimen yksilöllistä tuntemista (Buller \& Morris 2003).

Luonnonsuojelulliset ja eläinten hyvinvointia korostavat pyrkimykset ovat lisänneet eläinten "luonnollistamista", niiden näkemistä luonnollisina eläiminä, joilla on lajityypilliset käyttäytymistarpeet (Buller \& Morris 2003.) Tämä heijastaa myös luonnontieteellisen eläinten hyvinvointitutkimuksen ja siihen liittyvän tieteellistävän eläinsuhteen nousua (Birke 2008). Eläinten inhimillistämisessä tai luonnollistamisessa on pitkälti kysymys tulkinnasta: Esimerkiksi Lynda Birken (2008) tutkimuksessa hevosenomistajat näkevät hevosensa "toisena", vaistojensa sanelemana eläimenä, jota tulkitaan etäännyttävän, tieteellistävän diskurssin kautta. Toisaalta se mielletään kumppaniksi, ihmisen kaltaiseksi subjektiksi, joka osaa tehdä valintoja ja haluaa samoja asioita kuin ihminen.

Tieteellisen tiedon lisääntyessä on myös tieto eläinten pidosta ja hyvinvoinnista nykyään runsaampaa kuin koskaan. Hevosalan yleisselvityksissä (esim. Heiskanen ym. 2002) on kuitenkin esitetty, että uusien hevosenomistajien tiedoissa ja kokemuksessa on parannettavaa. Viime vuosikymmenten voimakas kasvu on tuonut hevosten pariin uusia toimijoita, usein aloittelevia hevosten omistajia, joilla on kaupunkilainen tausta. Oman hevosen pitäminen edellyttää paitsi kokemusta eläimen käsittelystä myös tietyssä määrin erityistietoa esimerkiksi ruokinnasta, koulutuksesta ja kengityksestä. Yhä harvemmalla nykyisistä hevosenomistajista on enää yhteyttä hevosten pidon perinteisiin, joten heidän on hankittava tietonsa hevosista muualta.

Tim Ingoldin $(2000,52)$ mukaan eläinten luonteenpiirteet, käyttäytyminen, temperamentti ja tunteet opitaan tuntemaan jokapäiväisessä kanssakäymisessä niiden kanssa. Myös hevosten pidossa käytännöllisen tiedon merkitys on perinteisesti ollut suuri (McShane \& Tarr 2007, 39). Agraariaikana taidot opittiin omalla kotitilalla käytännön esimerkin ja omakohtaisen kokemuksen kautta (Leinonen 2009). Tämä perinne on jatkunut ravihevosten pidossa ja osin myös ratsastuskulttuurissa. Ratsastuksen harrastajat oppivat hevostietonsa ja -taitonsa paitsi ratsastuskouluopetuksessa myös yhteisöllisen osallistumisen kautta ratsastustalleilla, joskus yhä kotona perhepiirissä, mikäli siihen on mahdollisuus (Birke 2008). Tältä pohjalta hevosten pitoon voidaan soveltaa hiljaisen tiedon (tacit knowledge) käsitettä. Hiljaisella tiedolla tarkoitetaan sellaista tietoa tai taitoa, jota on vaikea selittää sanoin - pitkälti on kyse eksplisiittisen, kirjoitetun tiedon vastakohdasta (Saaristo 2000). Hiljainen tieto on käytännöllistä ja hankitaan kokemuksen kautta, siksi se on myös henkilökohtaista.

Birken tutkimat hevosenomistajat sanovat "lukevansa" hevosensa käyttäytymistä ja sanattomia viestejä. Vastaavasti hevosen odotetaan lukevan omistajaansa; omistajalla on sitten vapaus tulkita hevosen ihmisestä tekemät tulkinnat haluamallaan tavalla (Birke 2008). Hevosenomistajat yrittävät myös tulkita hevostensa käyttäytymistä tieteellisen tiedon pohjalta, mutta käytännön tilanteissa tämä ei aina toimi. Luonnontiede on perinteisesti etäännyttänyt kohteensa passiiviseksi objektiksi, kun taas hevosenomistajat näkevät hevosensa ajattelevana ja tuntevana subjektina; tosin tällainen eläinkäsitys on viime aikoina tullut mukaan myös etologisiin tutkimuksiin (Birke 2008). Hevosenomistajille ristiriita ilmenee dualistisena ongelmana: hevosista puhutaan tieteellisesti yleisellä tasolla, lajina, mutta yksilöstä puhuttaessa se mielletään kumppaniksi ja subjektiksi. 


\section{Aineisto ja menetelmät}

Tämän tutkimuksen aineistona ovat yhdeksän itäsuomalaisten hevosenomistajien teemahaastattelut. Valitsin haastateltavat lumipallomenetelmällä (Atkinson \& Flint 2001): ensimmäisiltä haastateltavalta kysyttiin useampia jatkohaastateltavia, ja näistä valikoitiin sopivat mahdollisimman suuren informaatioarvon perusteella (Flyvbjerg 2001). Haastateltavat olivat kaikki naisia, iältään 20-60-vuotiaita, ja he omistivat haastatteluhetkellä kukin vähintään yhden ratsuhevosen. Samalla he toimivat muissa rooleissa hevosten parissa: ratsastuksenopettajina, valmentajina, kasvattajina, tallinpitäjinä tai kilparatsastajina.

Kysyin haastateltavilta ensin heidän omasta hevosharrastustaustastaan tai -ammatistaan, eläinten merkityksestä elämässään sekä omasta hevosten pidostaan, sen motiiveista, käytännöistä ja siinä koetuista ongelmista. Varsinaiset haastattelukysymykset käsittelivät esimerkiksi tiedon hankintaa ja tulkintaa, kokemuksen merkitystä sekä hevosen hyvinvoinnin tunnusmerkkejä. Haastattelut kestivät keskimäärin puolitoista tuntia, ja ne nauhoitettiin.

Koodasin litteroidut haastattelutekstit teemoihin (Eskola \& Suoranta 1998), joista tässä artikkelissa käsittelen eläinsuhteeseen tietoon ja hyvinvointiin liittyviä teemoja. Teemoitteluun valikoin yksittäisiä ilmaisuja, lauseita tai pidempiä kappaleita, ja ne saattoivat viitata teemoihin eri tavoin: lausuttuina mielipiteinä, kerrottuina henkilökohtaisina kokemuksina tai jonkin seikan tai esimerkiksi hevosen sanallisena kuvailuna. Teemoittelin koko aineiston samalla tavoin riippumatta siitä, mihin haastattelukysymykseen mikin vastaus oli annettu. Teemoihin luokitellut tekstikohdat jaottelin edelleen alateemoihin, jotka määrittyivät osittain myös aineiston perusteella. Keskeisiä alateemoja olivat esimerkiksi käsitys hevosesta eläimenä, hiljainen ja kokemusperäinen tieto sekä tiedon suhteellisuus.

Seuraavaksi pelkistin teemoitellun aineiston niin, että jätin samaa asiaa toistavat tekstikohdat pois. Jäljelle jääneet tekstinkohdat kokosin edelleen suuremmiksi kokonaisuuksiksi siten, että ne oli mahdollista lukea suhteessa tutkimuskysymyksiin, jotka olivat siinä vaiheessa tarkentuneet aineiston alustavan analyysin perusteella. Suurin tarkennus liittyi siihen, miten hevosen rooli ilmeni haastatteluissa eri konteksteissa. Lopuksi jäsentelin aineistosta valitut kohdat tämän tarkennetun luokituksen mukaisiksi teemoiksi, joissa uusia olivat entisiin nähden hevonen toimijana sekä hevosen subjektiivinen tunnekokemus.

\section{Tulokset ja tulosten tarkastelu}

Hevosiin suhtautumisen muutos näkyy haastatteluissa selvästi. Emotionaalinen suhde hevoseen on 2000luvun hevosenomistajalle tärkeä, vaikka hevosta käytettäisiin esimerkiksi kilpailuihin: eräs tällainen haastateltava mieltää hevosen älykkääksi subjektiksi jota täytyy "kunnioittaa" ja "rakastaa", jotta se voisi hyvin. Toisen haastateltavan mielestä hevosiin suhtautumisessa on nähtävissä myös uutta välineellisyyttä: "hevoset näyttää hyviltä ja niitä varustellaan hyvin, ja hirveesti valmentaudutaan, mutta on tullu semmonen välinpitämättömyys. Sit ne vaan heitetään noihin, sit ne vaan on siellä ja... on menny toiseen äärimmäisyyteen, niinku tää yliloimittaminen, ylivarustelu..." Samaan viittaa toinen, yli 20 vuotta hevosten kanssa toiminut haastateltava: "hevosia hoidetaan enemmän, mut sit myöskin liikaa." Tämän haastateltavan mielestä inhimillistäminen on lisääntynyt hevosten pidossa verrattuna 1980-lukuun, jolloin hän itse aloitti hevosharrastuksen: "hevoset oli hevosempia sillon."

Hevosta inhimillistetään haastatteluissa sanomalla esimerkiksi, että se on "ansainnut" hyvät eläkepäivät tehtyään pitkään töitä ihmiselle. Haastateltavat myös pohtivat hevosten omaa näkökulmaa ja subjektiivisuutta: "toiset hevosethan on hirmu semmosia konemaisia tavallaan, et ne tekee just niinku ihminen pyytää ... ajatteleeks hevonen et se ois sille helpointa, tai et onks se niin pahasti tottunu siihen." Tässäkin ratkaisuksi haetaan lopulta hevosen omaa, subjektiivista, ihmisen kaltaista "ajattelua". Eräs haastateltava kuvailee hevostaan selllaisena, kun hän kohtaa sen tullessaan tallille: "vaikka siis ei oo onnellista hevosta, mut se on siis periaatteessa onnellisen näkönen." Haastateltava käyttää antropomorfistista ilmaisua, vaikka ei itse täysin hyväksy sitä. Näin käsitys eläimistä toisaalta vaikuttaa siihen, miten hevosta tulkitaan, toisaalta se voi olla tulkinnan kanssa ristiriidassa. Eläinsuhde ei siis ole yksitasoinen, vaan se muodostuu kerroksellisesti tiedon, hankittujen kokemusten ja erilaisten tulkintojen varaan. 
Tiedon keskeisimpänä sisältönä mainitaan haastatteluissa hevosen tunteminen eläimenä, ja tässä biologinen, luonnollistava käsitys tulee selkeästi esiin puheena hevosesta "saaliseläimenä". Hevosta pyritään silti kohtelemaan yksilönä siten, että hoito ja työ pitää järjestää hevosen mukaan, "hevosen ehdoilla”. Luonnollisuus tulee ilmi myös tiettyjen hevostenkäsittelytapojen perusteena. Eräs ns. luonnilliseen hevostaitoon perehtynyt haastateltava pohtii, ettei siinä "koko touhussa välttämättä oo sikäli hevosystävällistä mikään, mut toisaalta se periaatteessa kuitenki perustuu siihen, mitä hevoset laumassa luonnossaki tai silleen tekee." Tässä luonnollisuutta ei liitetä hevosen hyvinvointiin. Joskus hevonen kuitenkin nähdään myös valintoja tekevänä subjektina, jolla on eläimen lajityypilliset tarpeet: "mitä hevonen mieluiten tekis, jos se vaan sais valita, niin sehän söis, se nukkus, se kävelis laitumella, tekis varsoja."

Hiljaisen tiedon merkitys tulee haastatteluissa esiin eräänlaisena intuitiivisena vaistona, tunteena, että asian on oltava näin. Tuota tunnetta on vaikea perustella edes itselle; kuten eräs haastateltava sanoo, hänellä on "hirveen vahva mutu" siitä, miten asiat on tietyssä tilanteessa tehtävä. Jälkeenpäin tuo mutukäsitys osoittautuu usein oikeaksi. Haastateltavat itse tulkitsevat, että tällainen tietämys perustuu ensisijaisesti kokemukseen. Haastateltavat kertovat myös, että kokemuksen kautta kertyvä tieto vaikuttaa heidän toimintaansa hevosten kanssa, ja kokemus tai sen puute ymmärretään myös omien onnistumisten ja epäonnistumisten selittäjänä.

Hevosen kanssa kommunikoidessa, sitä hoitaessa ja käsitellessä pienten merkkien huomaaminen ja tulkitseminen on olennaista. Kuten Birken (2008) tutkimuksessa, myös tässä haastateltavat kutsuvat sitä hevosen "lukemiseksi": "Sillon tää elämä hevosten kanssa tulee paljon helpommaksi, (...) kun oot oppinu lukemaan hevoselta sen vastauksen, eikä tarvii pohtia, et miksi tämä hevonen nyt kiukuttelee." Kyse on hiljaisesta tiedosta, jonka kontekstina on toiminnallinen, käytännöllinen suhde hevoseen sekä hevosen tunteminen yksilötasolla. Hevosen lukeminen ei ole pelkästään viestintää, hevosen ilmeiden tai eleiden tulkintaa, vaan siihen kuuluu myös hoitajan kyky tehdä johtopäätöksiä hevosen hyvinvoinnista tarkkailemalla sen yleisolemusta, käyttäytymistä eri tilanteissa, fyysistä ja psyykkistä tilaa ja kuntoa sekä talliympäristössä näkyviä merkkejä. Tällaisia saattavat olla esimerkiksi hevosen "apaattisuus" tai "iloisuus", myös sen sosiaalisuus sekä tapa kohdata ihminen arkisessa hoito- tai käsittelytilanteessa. Kuten eräs haastateltava sanoo, hevosten "silmistä näkee hirveen paljon että millä mielellä ne on". Vammojen tai sairauksien oireiden lisäksi hoitajan huomion voi kiinnittää hevosen ruokahalu ja syöminen, sen tapa liikkua tai liikunnan määrä.

Hevosen yksilöllinen tunteminen ilmenee esimerkiksi maininnassa, että hevosia tarhoihin laitettaessa "pitää olla semmosta ymmärrystä, että mitkä hevoset sopii keskenään ja mitkä ei sovi keskenään." Hevonen saattaa myös aktiivisesti toimia siten, että hoitajan on kyettävä tulkitsemaan sen viestejä. Se saattaa esimerkiksi haluta päästä tallista ulos tai talliin sisälle. Tällöin hevosesta itsestään tulee subjekti, jonka toimintaa hoitaja tulkitsee: "jos ne tossa nököttää portilla, on sen näkösinä että ei, tääl on hirveetä, niin mie sanon et sen kun tulette sisälle". Toisessa tilanteessa tulkinta liittyy hevosen kokemuksiin ja tuntemuksiin: "näki selvästi että se ei halunnu lähtee (tallista ulos aamulla), elikkä varsominen on jo niin lähellä. Elikkä se kokee sen karsinapaikan turvallisempana." Hevosen tulkitaan myös tekevän johtopäätöksiä itseään koskevista asioista: "Meillä se vanha tamma, niin tota, ei se ees sokeria syöny. Et se niinku käytti sen suussa ja pulautti sen pois. Ja se varmaan ties, et se ei oo hänelle hyväks." Tulkinta on siis usein inhimillistävää, mutta se voi myös pyrkiä verbalisoimaan hevosen näkökulmaa, ikään kuin puhumaan hevosen puolesta.

Ne haastateltavat, joilla on hevosia omassa tallissa kotonaan, kuvailevat hevosen lukemista monipuolisemmin kuin ne, joiden hevoset asuvat täysihoitotallilla, missä he itse eivät ole yhtä paljon paikalla. Tyypillinen esimerkki on aamuisen karsinan tulkinta: jos karsina on yön jäljiltä sotkuinen, lanta näyttää erilaiselta kuin yleensä tai heiniä on jäänyt syömättä, se saattaa olla merkki ongelmista. Hevosiaan kotona pitävä haastateltava sanoo:

"täyshoidossa on heti se ikävä puoli, että sä et tiedä. Sä et tiie aamulla, päivällä, illalla, et mitä sun hevoselle kuuluu. Et mä tiien heti et aha, kaikki ei oo normaalii, jos kakkakasat on eri paikassa tai heinää on syömättä tai... Et niinku mä nään karsinastaki et mitä kuuluu. Et moni eri asia niinku kertoo mulle sen hevosen hyvinvoinnista." 
Hevosten kotona pitämisen motiivina siis on, että hevosen lukeminen arjessa on helpompaa kuin jos hevonen olisi täysihoitotallissa. Hevosia täysihoidossa pitävälle taas eläinten hyvä kunto on myös sosiaalinen kysymys: "ei tartte hävetä ku niiden kanssa lähet jonneki muualleki."

\section{Johtopäätökset}

Haastatteluista ilmenee, että emotionaalisuus on keskeistä harrastehevosten omistajien eläinsuhteessa, mutta siinä on myös viitteitä välineellisestä ajattelusta (Franklin 1999). Hevosen määrittäminen myöhäismodernissa kontekstissa seuraeläimeksi on silti perusteltua. Välineellisyys liitetään hevosten pidon muutokseen, uusiin hoitokäytäntöihin ja ennen kaikkea muihin toimijoihin. Välineellisyyteen liittyy voimakkaasti negatiivisia konnotaatioita; ajatus hevosesta välineenä on ristiriidassa seuraeläin-käsityksen kanssa ja hyvän eläintenpidon periaatteiden kanssa. Vaikka hevosia käytetään monenlaisissa tehtävissä ja tähän suhtaudutaan sinänsä arkisesti, ei omaa eläintä, johon on luotu tunneside ja josta kannetaan moraalista vastuuta, haluta mieltää välineenä.

Hevosenomistajat tulkitsevat hevosiaan usein inhimillistävästi, mutta toisaalta myös luonnontieteellisesti tai luonnollistavasti. Kuten Birken (2008) tutkimuksessa, tieteellinen tulkinta painottuu enemmän yleisen tason kuvauksiin, missä hevonen nähdään eläinlajina. Luonnollistavaa tulkintaa, jossa eläimen biologista olemusta korostetaan, käytetään kuitenkin myös yksilötasolla inhimillistävän tulkinnan rinnalla (Buller \& Morris 2003). Tällöin eläimen tuntoja ja toimintaa tulkitaan verbaalisesti, mutta sitä ei verrata ihmiseen, vaan se nähdään nimenomaan eläimenä. Tulkinnan tarkoituksena on päästä perille siitä, miltä hevosesta tuntuu hevosena. Tällaista empaattista tulkintaa voisi kuvata myös eläimen puolesta puhumisena (Arluke \& Sanders 1996).

Inhimillistävän ja luonnollistavan tulkinnan erolla on todellista merkitystä silloin, kun niitä käytetään toiminnan lähtökohtana hevosten hoidossa tai käsittelyssä. Kun eläin nähdään eläimenä, tulkinta perustuu siihen, mitä eläimestä tiedetään ja millainen käsitys siitä on muodostunut tuon tiedon pohjalta. Myös hevosen tunteminen yksilönä on tärkeää. Tieteeseen perustuvasta, eksplisiittisestä tiedosta pyritään hakemaan yleisiä ohjeita ja käsitystä hevosesta luonnollisena eläimenä. Tieteellisen tiedon rinnalla merkittäväksi nousee hiljainen tieto, joka ilmenee hevosten pidossa käytännöllisen kokemuksen antamana intuitiivisena varmuutena, mutta myös erityisenä taitona "lukea" hevosta ja tulkita sen viestejä ja olotilaa. Tällä on keskeinen merkitys eläimen hyvinvoinnin määrittämisessä arkisissa hoito- ja käsittelytilanteissa. Hyvinvointia määritetään sekä inhimillistävistä että luonnollistavista lähtökohdista sen mukaan, minkätyyppisen tiedon ja kokemusten pohjalta eläintä tulkitaan.

Käytännön tilanteissa ja niistä tehtävissä tulkinnoissa tiedon eri lajit kietoutuvat yhteen. Haastattelujen pohjalta merkittävää on myös eläinsuhteen monitasoisuus: antropomorfistisia ilmaisuja käytetään emotionaalisissa kuvauksissa eläimistä samanaikaisesti, kun eläintä ja sen tarpeita kuvataan luonnontieteellisen tiedon perusteella. Eläinsuhde rakentuukin kerroksellisesti eksplisiittisen tiedon, hankittujen kokemusten sekä inhimillistävän ja luonnollistavan tulkinnan varaan, ja käsitykset eläimistä tuottavat myös ristiriitaisia tulkintoja. Tämä heijastuu siihen, minkälaista hoitoa ja käsittelyä lopulta pidetään oikeana ja "hevosystävällisenä".

Omistajan suhde hevoseen, kokemus ja taito lukea hevosta antavat myös hevoselle itselleen roolin toimivana subjektina, joka osallistuu itseään koskevan tiedon muodostamiseen. Siten se pääsee välillisesti myös vaikuttamaan omaan hyvinvointiinsa, niin kuin Buller ja Morris (2003) ehdottavat. Olennaista siinä on ihmisen kyky tulkita eläintä monitasoisesti ja monenlaisen tiedon pohjalta.

\section{Kirjallisuus}

Arluke, A. \& Sanders, C. R. 1996. Regarding Animals. Temple University Press, Philadelphia.

Atkinson, R. \& Flint, J. 2001. Accessing Hidden and Hard-to-Reach Populations: Snowball Research Strategies. Social Research Update 3/2001. Verkkojulkaisu / http://sru.soc.surrey.ac.uk/SRU33.html. (Luettu 26.1.2009.) 
Birke, L. 2008. Talking about Horses: Control and Freedom in the World of "Natural Horsemanship". Society and Animals 16:2, 107-126.

Buller, H. \& Morris, C. 2003. Farm Animal Welfare: a New Repertoire of Nature-Society Relations or Modernism Re-embedded? Sociologia Ruralis 43:3, 216-237.

Eskola, J. \& Suoranta, J. 1998. Johdatus laadulliseen tutkimukseen. Vastapaino, Tampere.

Flyvbjerg, B. 2001. Making Social Science Matter: Why social inquiry fails and how it can succeed again. Cambridge University Press, Cambridge.

Franklin, A. 1999. Animals and modern cultures. A Sociology of Human-Animal Relations in Modernity. Sage Publications, London.

Hall, S. J.G. 2005. The horse in human society. Teoksessa Daniel Mill \& Sue McDonnell (toim.). The Domestic Horse. The Evolution, Development and Management of its Behaviour. Cambridge University Press.

Haraway, D. J. 2008. When Species Meet. University of Minnesota Press, Minneapolis.

Heiskanen, M.-L., Klemola I., Kumpulainen, M. \& Kauppinen, P. 2002. Hevostalous - merkitys ja tulevaisuus Suomessa. Hevostietokeskus, Kuopio.

Ingold, T. 2000. The Perception of the Environment. Essays in livelihood, dwelling and skill. Routledge, London and New York.

Kupsala, S. 2007. Eläinten hyvinvointia ja teurastusta koskevat dilemmat: Maatalouseläinten ambivalentti asema. Maaseudun uusi aika 15:2, 19-34.

Leinonen, R.-M. 2009. Finnish horse culture and the changing human-horse relationship. Julkaisematon käsikirjoitus.

McShane, C. \& Tarr, J. A. 2007. The Horse in the City. Living Machines in the Nineteenth Century. The Johns Hopkins University Press, Baltimore.

Saaristo, K. 2000. Avoin asiantuntijuus. Ympäristökysymys ja monimuotoinen ekspertiisi. Jyväskylän yliopisto, Nykykulttuurin tutkimuskeskuksen julkaisuja 66, Jyväskylä.

Schuurman, N. 2010. Eläinsuhde, tieto ja asiantuntijuus. Tapauksena hevosten pito. Sosiologia, ilmestyy numerossa $1 / 2010$.

Serpell, J. 2003. Anthropomorphism and Anthropomorphic Selection - Beyond the "Cute Response". Society \& Animals 11:1, 83-100.

Serpell, J. \& Paul, E. 1994. Pets and positive attitudes to animals. Teoksessa Aubrey Manning \& James Serpell (toim.). Animals and Human Society - Changing Perspectives. Routledge, London. 